\title{
Ekologinio tręšimo įtaka NPK balansui ir maisto medžiagų dinamikai dirvožemyje
}

\author{
Vilma Žèkaité ${ }^{1}$, \\ Gediminas Staugaitis ${ }^{1}$, \\ Jonas Arbačiauskas ${ }^{1}$, \\ Juozas Pekarskas², \\ Tomas Adomaitis ${ }^{1}$, \\ Donatas Šumskis ${ }^{1}$, \\ Zigmas Vaišvila ${ }^{1}$ \\ ${ }^{1}$ Lietuvos agrarinių ir mišku \\ mokslu centras, \\ Instituto al. 1, \\ LT-58344 Akademija, Kédainių r. \\ ${ }^{2}$ Aleksandro Stulginskio universitetas, \\ Studentug. 11, \\ LT-53361 Akademija, Kauno r. \\ El.paštas: bandymai@agrolab.lt
}

Tyrimų tikslas - ịvertinti azoto, fosforo ir kalio balansą ekologinèje keturlaukèje sejjomainoje, nustatyti jo ịtaką lengvos granuliometrinès sudèties dirvožemio agrocheminėms savybėms bei cheminių elementų išplovimui, įvertinti šios tręšimo sistemos tinkamumą ekologiniam ūkininkavimui.

Augalų maisto medžiagų balanso tyrimai ekologinès žemdirbystès sistemoje vykdyti 2006-2009 m. paprastajame, pajaurejusiame išplautžemyje (IDe-p), smèlingame priemolyje (Hapli-Albic Luvisol (LVa-ha), sandy loam). Dirvožemio ariamojo sluoksnio $\mathrm{pH}_{\mathrm{KCl}}$ buvo 5,2-6,3; $\mathrm{P}_{2} \mathrm{O}_{5} 190-253 ; \mathrm{K}_{2} \mathrm{O}-134-178 \mathrm{mg} \mathrm{kg}^{-1}$, o humuso - 1,83\%. Lauko sèjomainoje auginti sideraliniai lubinai, žieminiai rugiai, bulvès ir vasariniai miežiai.

Ekologinejje žemdirbystès sistemoje, augalus tręšus méšlu, žaliąja trąša ir šiaudais, taip pat mineralinėmis kalio trą̌šmis, azoto, fosforo ir kalio balanso pajamos viršijo jų išlaidas atitinkamai 55,6-62,7; 23,3-25,8 ir 107-119 kg ha-1.

Rugius, bulves, miežius patręšus ir azoto organine trąša Provita, azoto balanso pajamos viršijo išlaidas net $93,9-103 \mathrm{~kg} \mathrm{ha}^{-1}$ ir gerino fosforo bei kalio pasisavinimą.

Dèl ekologinių trąšų naudojimo humuso ir judriojo fosforo kiekis per sëjomainos rotaciją dirvožemyje beveik nepakito, o judriojo kalio kiekis padidèjo $47 \mathrm{mg} \mathrm{kg}^{-1}$.

Cheminių elementų išplovimas iš dirvožemio didesnis vasaros-rudens nei žiemos-pavasario laikotarpiu. Kiek daugiau išsiplovė kalio, mažiau - azoto, o mažiausiai - fosforo.

Raktažodžiai: ekologinès trąšos, balansas, agrocheminiai rodikliai, $\mathrm{N}, \mathrm{P}_{2} \mathrm{O}_{5}$ ir $\mathrm{K}_{2} \mathrm{O}$ išplovimas

\section{IVADAS}

Ekologiškai ūkininkaujant didejja dirvožemio biologinè įvairove, sumažeja augalų maisto medžiagų išplovimas bei dirvožemio erozijos rizika, o žemès ūkio augalų produkcija būna kokybiškesnè negu intensyvios gamybos ūkiuose (Mander, Mikk, Külvik, 1999; Brandt, Mølgaard, 2001).

Lietuvos ekologinès gamybos ūkių dirvožemiụ sukultūrinimas dažnai yra nepakankamas, kad būtų užaugintas geras žemès ūkio augalų derlius, nes $18,6 \%$ dirvožemių yra rūgštūs, o 36,5 ir $16 \%$ mažo ir tik 26,2 ir 45,6 \% - pakankamo fosforingu- mo ir kalingumo, o 52,4 \% tirtų dirvožemių nustatytas mažas humusingumas (Mažvila ir kt., 2003). Šveicarijoje, plètojant ekologinès žemdirbystès sistemas, dirvožemyje randami mažesni judriujų fosforo ir kalio, tačiau didesni kalcio ir magnio kiekiai negu iprastinèje žemdirbystès sistemoje (Niggli et al., 1995), kadangi ekologinès gamybos ūkiuose negalima naudoti sintetinių azoto, fosforo ir kalio trąšų, taip pat organinių trą̌š iš pramoninès žemdirbystès ūkių.

Europos Sajungos nuostatose nurodoma, kad ekologinè augalų produktų gamyba turètuc padèti išlaikyti ir pagerinti dirvožemio derlingumą, 
nealinti dirvožemių bei nebloginti jų agrocheminių savybiu (Commision Regulation..., 2010; Council Regulation, 2010), neteršti vandenų nitratais (HELCOM Recomendation, 2007).

Siekiant tausojančiai naudoti dirvožemio išteklius, padidinti žemès ūkio augalų produktyvumą mažinant vandenų ir oro teršimą augalų nesunaudotomis maisto medžiagomis, dirvožemyje skaičiuojami augalų maisto medžiagų balansai (Karklins, Lipenite, 1998; Parris, 1998). Ekologinès gamybos ūkiuose, kur trąšų panaudojimas labai apribotas, ypač svarbu, kad augalų maisto medžiagų balansas užtikrintų gerą žemès ūkio augalų derlingumą ir išsaugotų dirvožemio našumą (Watson et al., 2002).

Ekologinès žemdirbystès sistemoje, trūkstant organinių ir mineralinių trąšų bei esant mažam jų pasirinkimui, augalų maisto medžiagų balansas dirvožemyje dažniausiai būdavo neigiamas (Haraldsen et al., 1999; Pekarskas ir kt., 2003). Ši problema ypač aktuali šalyse ar jų regionuose, kur auginama mažai gyvulių ir mažai sukaupiama mèšlo (Bachinger, Stein-Bachinger, 2000). Tačiau ekologiniu požiūriu augalų maisto medžiagų balansai ekologinès gamybos ūkiuose dažniausiai būdavo gaunami patenkinami (Freyer, Pericin, 1996).

Pastaruoju metu didejant sertifikuotų ekologinès gamybos ükiams naudojamų trąšu asortimentui atsiranda galimybè augalus geriau aprūpinti maisto medžiagomis. Tobulinamos augalų tręšimo sistemos ekologinès gamybos ūkiams, kurios leistų sudaryti augalams geresnes mitybos sąlygos, nebūtų teršiama gamta, nealinamas dirvožemis (Niggli et al., 1995; Bachinger, Stein-Bachinger, 2000; Pekarskas, 2008).

Tyrimų tikslas - jivertinti azoto, fosforo ir kalio balansą ekologinëje keturlaukèje sejjomainoje, nustatyti jo ịtaką lengvos granuliometrinès sudèties dirvožemio agrocheminėms savybèms bei cheminių elementų išplovimui, ịvertinti šios tręšimo sistemos tinkamumą ekologiniam ūkininkavimui.

\section{TYRIMU SALYGOS IR METODAI}

Dirvožemis. Ekologinio tręšimo įtaka NPK balansui ir biogeninių elementu migravimui tirta 2006-2009 m. Pietryčių Lietuvoje, LAMMC filiale, Perlojos bandymų stotyje $\left(54^{\circ} 14^{\prime} 11.28^{\prime \prime} \mathrm{N}\right.$, $25^{\circ} 24^{\prime} 51.57^{\prime \prime E}$ ). Dirvožemis - Hapli-Albic Luvisol (LVa-ha), sandy loam. Dirvožemio èminiai nustatant judriuosius $\mathrm{P}_{2} \mathrm{O}_{5}$ ir $\mathrm{K}_{2} \mathrm{O}$, humusą ir $\mathrm{pH}_{\mathrm{KCl}}$ buvo paimti visų laukelių iš $0-20 \mathrm{~cm}$ dirvožemio sluoksnio prieš eksperimento įrengimą ir jị užbaigus. Dirvožemio ariamasis sluoksnis prieš ịrengiant bandymą buvo mažo rūgštumo ir neutralus $\left(\mathrm{pH}_{\mathrm{KCl}} 5,2-6,3\right)$, didelio fosforingumo $-\mathrm{P}_{2} \mathrm{O}_{5} 190-$ $253 \mathrm{mg} \mathrm{kg}^{-1}$ ir vidutinio kalingumo $-\mathrm{K}_{2} \mathrm{O}-134-$ $178 \mathrm{mg} \mathrm{kg}^{-1}$, o humuso - 1,77-1,87 \%.

\section{TYRIMỤ SCHEMA IR JOS DETALĖS}

Tyrimai vykdyti keturlaukejje sëjomainoje, kurioje kasmet buvo auginami lubinai, žieminiai rugiai, bulvès ir vasariniai miežiai. Žemès ūkio augalai tręšti ekologinès gamybos ūkiuose leidžiamomis naudoti organinėmis ir mineralinėmis trąšomis, jų normos, išreikštos $\mathrm{N}$ ir $\mathrm{K}_{2} \mathrm{O}$, nurodytos 1 lentelèje. Vieną kartą per sejomainą bulvèms įterpta $50 \mathrm{t} \mathrm{ha}^{-1}$ kraikinio mëšlo, kurio sudetyje $\mathrm{N}, \mathrm{P}_{2} \mathrm{O}_{5}$ ir $\mathrm{K}_{2} \mathrm{O}$ buvo atitinkamai 0,$55 ; 0,29$ ir $0,62 \%$. Visi augalai tręšti ir mineralinemis kalio trąšomis - lubinai, žieminiai rugiai ir vasariniai miežiai Kornkali, o bulvès - Patentkali trąšomis, kurių sudètyje buvo atitinkamai 40 ir $30 \%$ $\mathrm{K}_{2} \mathrm{O}$. Žieminiai rugiai, bulvès ir vasariniai miežiai kai kuriuose eksperimento laukeliuose tręšti ir organine azoto trąša Provita, kurioje buvo 13,5 \% N. Lubinų žalioji masė užarta, žieminių rugių ir vasarinių miežių šiaudai irgi paskleisti ir užarti. Kai kuriuose laukeliuose kaip tarpiniai augalai buvo auginti žieminiai rapsai (ž. r.), jie buvo užarti žaliajai trąšai. Augalų pagrindinès ir šalutinès produkcijos èminiai cheminèms analizèms buvo paimti derliaus nuèmimo metu, o lubinų - prieš jų užarimą.

Augaluose ir organinèse trąšose suminis $\mathrm{N} \mathrm{nu-}$ statytas Kjeldalio, suminis $\mathrm{P}$ - vanadato-molibdato, suminis $\mathrm{K}$ - fotometriniu metodu. Augaluose cheminiai elementai nustatyti sausoje, o organinèse trąšose - natūralaus drègnumo medžiagoje.

Apykaitos energijos kiekis augalu produkcijoje apskaičiuotas pagal T. Tamulio analizių duomenis (1986; Jankauskas ir kt., 2000).

Be to, kai kuriuose laukeliuose per lapus augalai buvo tręšiami trąšomis Biokal (b. k.) ir Biojodžiu (b. j.). Organines trąšas Biokal sudaro $57 \%$ vaistažolių ekstrakto, $38 \%$ vandeninio biohumuso ekstrakto ir $5 \%$ eterinio aliejaus, mineralinio vandens ir mikroelementų. $\mathrm{N}$ jose yra ne mažiau $0,023 \% ; \mathrm{P}_{2} \mathrm{O}_{5}-0,037$, o $\mathrm{K}_{2} \mathrm{O}$ ne mažiau $0,048 \%$. Biojodžio sudètyje yra 0,85-1,5 \% N; $0,90-1,5 \% \mathrm{P}_{2} \mathrm{O}_{5} ; 0,820-1,50 \% \mathrm{~K}_{2} \mathrm{O}$, vandenyje tirpių humatų - 0,15-0,700\%; $\mathrm{CaO}-0,40-2,0 \%$; $\mathrm{MgO}-0,25-2,0 \%$, ivvairių mikroelementų. 
1 lentelè. Žemès ūkio augalų tręšimo schema ekologinèje sẻjomainoje

Table 1. Crop fertilization in organic crop rotation scheme

\begin{tabular}{|c|c|c|c|c|}
\hline 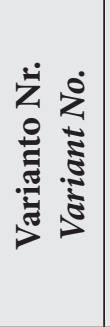 & 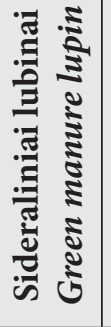 & $\begin{array}{l}\text { Žieminiai rugiai* } \\
\text { Winter rye }^{\star}\end{array}$ & $\begin{array}{l}\text { Bulvès }^{* *} \\
\text { Potatoes }^{\star *}\end{array}$ & $\begin{array}{l}\text { Vasariniai miežiai* }^{\star} \\
\text { Spring barley }\end{array}$ \\
\hline 1 & $\mathrm{~K}_{60}$ & $\mathrm{~K}_{60}$ & $K_{120}$ & $\mathrm{~K}_{60}$ \\
\hline 2 & $\mathrm{~K}_{60}$ & $\mathrm{~K}_{60}$ Provita $\mathrm{N}_{30}$ & $\mathrm{~K}_{120}$ Provita $\mathrm{N}_{90}$ & $\mathrm{~K}_{60}$ Provita $\mathrm{N}_{60}$ \\
\hline 3 & $\mathrm{~K}_{60}$ & $\begin{array}{c}\mathrm{K}_{60}+\text { žieminiai rapsai } \\
\text { winter rape }\end{array}$ & $\begin{array}{c}\mathrm{K}_{120}+\text { žieminiai rapsai } \\
\text { winter rape }\end{array}$ & $\begin{array}{c}\mathrm{K}_{60}+\text { žieminiai rapsai } \\
\text { winter rape }\end{array}$ \\
\hline 4 & $\mathrm{~K}_{60}$ & $\mathrm{~K}_{60}+$ Biokal & $\mathrm{K}_{120}+$ Biokal & $\mathrm{K}_{60}+$ Biokal \\
\hline 5 & $\mathrm{~K}_{60}$ & $\mathrm{~K}_{60}$ Provita $\mathrm{N}_{30}+$ Biojodis & $\mathrm{K}_{120}$ Provita $\mathrm{N}_{90}$ & $\mathrm{~K}_{60}$ Provita $\mathrm{N}_{60}+$ Biojodis \\
\hline 6 & $\mathrm{~K}_{60}$ & $\begin{array}{l}\mathrm{K}_{60} \text { Provita } \mathrm{N}_{30}+\text { winter } \\
\text { rape + Biokal + Biojodis }\end{array}$ & $\begin{array}{c}\mathrm{K}_{120} \text { Provita } \mathrm{N}_{90}+\text { winter } \\
\text { rape }+ \text { Biokal }\end{array}$ & $\begin{array}{l}\mathrm{K}_{60} \text { Provita } \mathrm{N}_{60}+\text { winter } \\
\text { rape + Biokal + Biojodis }\end{array}$ \\
\hline
\end{tabular}

Pastaba: ${ }^{\star}$ užarti šiaudai, ${ }^{* *}$ tręšta $50 \mathrm{t} \mathrm{ha}^{-1}$ méšlo.

Note: ${ }^{*}$ ploughed in straw, ${ }^{* *}$ fertilized with 50 tha-1 manure.

\section{Cheminių medžiagų išplovimo tyrimai}

Vandenys iš lizimetrų, įrengtų $40 \mathrm{~cm}$ gylyje, buvo siurbiami kiekvienais metais, pavasarị ir rudenị.

Ivertintas cheminių medžiagų koncentracijų lizimetriniuose vandenyse svertinis vidurkis atsižvelgiant $\mathfrak{i}$ atskirais metais iškritusių kritulių kiekị. Kritulių, iškritusių gegužès, birželio, liepos, rugpjūčio, rugsèjo ir spalio mèn., vidutinè metinè suma 2006, 2007, 2008 ir $2009 \mathrm{~m}$. buvo 514, 499, 395 ir $408 \mathrm{~mm}$, o lapkričio, gruodžio, sausio, vasario, kovo ir balandžio mèn. iškrito mažiau - 2006/2007; 2007/2008 ir 2008/2009 m., atitinkamai 272, 323 ir $211 \mathrm{~mm}$.

Iš dirvožemio išplautų cheminių medžiagų kiekiai $\left(\mathrm{kg} \mathrm{ha}^{-1}\right)$ apskaičiuoti cheminio elemento vidutinę koncentraciją $\left(\mathrm{mg} \mathrm{l}^{-1}\right)$ lizimetrų vandenyje padauginus iš atskirų metų kritulių kiekio $\left(\mathrm{m}^{3} \mathrm{ha}^{-1}\right)$ ir nuotekio koeficiento, kurio reikšmé Pietryčių Lietuvos priesmèlio silpnai banguoto reljefo dirvožemiams yra 0,35 (Jablonskis, Janukènienè, 1978). Vasaros ir žiemos sezonų metu iš dirvožemio išsiplovę $\mathrm{NO}_{3}^{-}, \mathrm{PO}_{4}{ }^{3-}$ ir $\mathrm{K}^{+}$kiekiai susumuoti, o gautos reikšmés perskaičiuotos i $\mathrm{N}, \mathrm{P}_{2} \mathrm{O}_{5}$ ir $\mathrm{K}_{2} \mathrm{O}$.

\section{Dirvožemio, augalų ir lizimetrinių vandenų cheminè analizè}

Dirvožemio $\mathrm{pH}_{\mathrm{KCl}}$ nustatytas elektrometriniu, judrieji $\mathrm{P}_{2} \mathrm{O}_{5}$ ir $\mathrm{K}_{2} \mathrm{O}$ - Egnerio-Rimo-Domingo (A-L) metodais. Humuso kiekis dirvožemyje apskaičiuo- tas analizatoriumi „Liqui TOC II“, nustatytą organinès $\mathrm{C}$ kieki padauginus iš koeficiento 1,726.

Augalų sausoje medžiagoje ir natūralios drègmès organinèse trą̌sose suminis $\mathrm{N}$ nustatytas Kjeldalio, suminis $\mathrm{P}$ - vanadato-molibdato, suminis $\mathrm{K}$ - fotometriniu metodu.

Nitratų $\left(\mathrm{NO}_{3}^{-}\right)$koncentracija lizimetriniuose vandenyse nustatyta naudojant sulfosalicilo rūgštị, fosfatu $\left(\mathrm{PO}_{4}^{3-}\right)$ - spektrometriniu metodu naudojant amonio molibdatą, o $\mathrm{K}^{+}-$liepsnos spektrometriniu metodu.

\section{Balanso skaičiavimas}

NPK balansas dirvožemyje yra ịvertintas kaip azoto, fosforo ir kalio, patekusių $\mathfrak{i}$ dirvožemị ir iš jo išneštų kiekių, skirtumas. Skaičiuojant panaudota daugelyje Europos šalių taikoma metodika (Parris, 1998; Bučienè ir kt., 2003; Karklins, Lipenite, 2006). Lubinų ir rapsų žaliojoje trąšoje, šiauduose, rapsuose ir iš dirvožemio sukauptos augalų maisto medžiagos buvo ịterptos ị dirvožemi, iš dirvos pašalintos nebuvo, todèl ir ị balansą neịskaičiuotos.

Lubinų biologiškai fiksuotas azoto kiekis apskaičiuotas pagal lubinų biomasèje fiksuotą kiekį, nes kiti autoriai yra nustatę, kad lubinai savo biomasèje sukaupia apie $50 \%$ simbiotinių bakteriju fiksuoto azoto kiekio. Su krituliais kasmet iškrinta apie $12 \mathrm{~kg} \mathrm{ha}^{-1}$ azoto nitratų ir amonio (Evans, 1987; Lapinskas, 2008). Minètą nitratų ir amonio 
kieki perskaičiavę i $\mathrm{N}$ gauname, kad su krituliais kasmet iškrinta apie $4 \mathrm{~kg} \mathrm{ha}^{-1}$ azoto.

Azoto nuostoliai dèl denitrifikacijos priesmèlio dirvožemiuose yra apie $30 \mathrm{~kg} \mathrm{ha}^{-1}$ per metus (Fagerberg et al., 1993).

Vidutinis augalų maisto medžiagų sunaudojimas per sejjomainą apskaičiuotas pagal $\mathrm{N}, \mathrm{P}_{2} \mathrm{O}_{5}$ ir $\mathrm{K}_{2} \mathrm{O}$ balanso išlaidų su jo pajamomis santykị.

Skaičiuojant augalų maisto medžiagų balansą dirvožemyje azotas buvo išreikštas grynu elementu - $\mathrm{N}$, o fosforas ir kalis - oksidais - $\mathrm{P}_{2} \mathrm{O}_{5}$ ir $\mathrm{K}_{2} \mathrm{O}, \mathrm{kg} \mathrm{ha}^{-1}$.

\section{Statistinè analizè}

Tyrimų duomenys apdoroti dispersinès analizès metodu naudojant kompiuterinę programą ANOVA (Clewer, Scarisbric, 2001). Dirvožemio agrocheminių rodiklių ir lizimetrinių tyrimų duomenų statistinis patikimumas ịvertintas pagal mažiausio skirtumo patikimumo ribą - $\mathrm{LSD}_{05}$.

\section{TYRIMŲ REZULTATAI IR JŲ APTARIMAS}

Azoto balansas dirvožemyje. Augalų maisto medžiagų balanso išlaidos didele dalimi priklauso nuo žemès ūkio augalų derlingumo, kuris ekologinėje žemdirbystès sistemoje yra mažesnis negu inten- syvioje (Parris, 1998; Masilionyte, Maikštėnienè, 2010). Tai atsispindi ir mūsu atliktuose eksperimentuose, kur žemès ūkio augalų derlius taip pat gautas nedidelis: lubinų žaliosios masès - 20,7-22,7 $\mathrm{t} \mathrm{ha}^{-1}$, žieminių rugių grūdų - 3,36-3,98, bulvių gumbų - 13,9-17,3, miežių grūdų - 2,05-2,60 t ha ${ }^{-1}$, o lauko séjomainos produktyvumas - 23,728,4 GJ ha ${ }^{-1}$ (2 lentelè).

Ivertinus $\mathrm{N}$ balanso pajamas, daugiausia jo $\mathfrak{i}$ dirvožemi pateko tuose sejjomainos laukuose, kur buvo auginami sideraliniai lubinai ir bulvès ( 3 lentelè). Su lubinais i dirvožemị iš viso pateko 165$195 \mathrm{~kg} \mathrm{ha}^{-1} \mathrm{~N}$, iš jų biologiškai - 153-183 $\mathrm{kg} \mathrm{ha}^{-1}$. Auginant bulves suminio $\mathrm{N} \mathfrak{i}$ dirvožemi iš viso buvo iterpta net $287-377 \mathrm{~kg} \mathrm{ha}^{-1}$, iš jo $275 \mathrm{~kg} \mathrm{ha}^{-1}$ pateko su kraikiniu méšlu. Be to, kai kuriuose laukeliuose bulvèms buvo itterpta $90 \mathrm{~kg} \mathrm{ha}^{-1} \mathrm{~N}$ organinès trąšos Provita. Žieminiams rugiams kai kuriuose laukeliuose buvo itterpta 30 , o vasariniams miežiams $-60 \mathrm{~kg} \mathrm{ha}^{-1} \mathrm{~N}$ organinès trąšos Provita (P. V.). Be to, nedideli N kiekiai į dirvožemi pateko su krituliais ir augalų sẻklomis.

Esant mažam žemès ūkio augalų derlingumui, juose buvo sukaupta mažai ir augalų maisto medžiagų. Rugių grūdų derliuje $\mathrm{N}$ sukaupta

\section{2 lentelè. Žemès ūkio augalų derlingumas ekologinëje sẻjomainoje}

Table 2. Productivity of agricultural crops in organic rotation

\begin{tabular}{|c|c|c|c|c|c|c|}
\hline \multirow[b]{2}{*}{$\begin{array}{l}\text { Žemès ūkio augalai } \\
\text { Agricultural crops }\end{array}$} & \multicolumn{6}{|c|}{$\begin{array}{l}\text { Vidutinè metinè tręšimo norma per sèjomainą } \\
\text { The average annual rate of fertilization in rotation }\end{array}$} \\
\hline & $z^{n}$ & 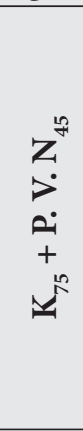 & 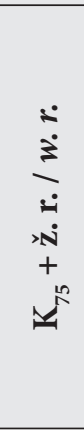 & 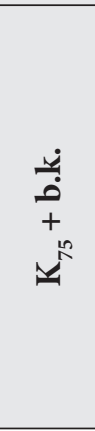 & 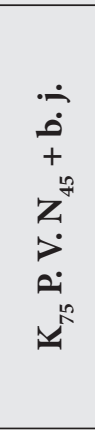 & 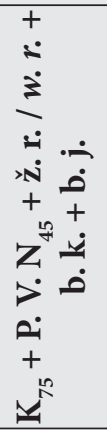 \\
\hline \multicolumn{7}{|c|}{ Derlingumas / Yield $\mathrm{t} \mathrm{ha}^{-1}$} \\
\hline $\begin{array}{l}\text { Lubinų žalioji masė sausąja medžiaga } \\
\text { Dry material of lupin green mass }\end{array}$ & 21,4 & 22,7 & 22,6 & 21,3 & 21,0 & 20,7 \\
\hline Žieminių rugių grūdai / Winter rye grains & 3,44 & 3,79 & 3,42 & 3,36 & 3,98 & 3,88 \\
\hline Bulvių gumbai / Potatoe tubers & 14,3 & 16,4 & 14,1 & 13,9 & 15,7 & 17,3 \\
\hline Vasarinių miežių grūdai / Spring barley grain & 2,05 & 2,12 & 2,07 & 2,12 & 2,55 & 2,60 \\
\hline \multicolumn{7}{|c|}{ Lauko sejjomainos produktyvumas / Field crop rotation productivity } \\
\hline Apykaitos energija / Metabolizable energy GJ ha-1 & 23,7 & 25,7 & 23,9 & 24,0 & 27,9 & 28,4 \\
\hline
\end{tabular}

Trąšos: P. V. - Provita; ž. r. - žieminių rapsų žalioji trąša; b. k. - Biokal; b. j. - Biojodis.

Fertilizers: P. V. - Provita; w. r. - winter rapeseed green manure; b. k. - Biokal; b. j. - Biojodis. 
3 lentelè. Azoto apykaita ekologinėje žemdirbystės sistemoje

Table 3. Metabolism of nitrogen in organic farm system

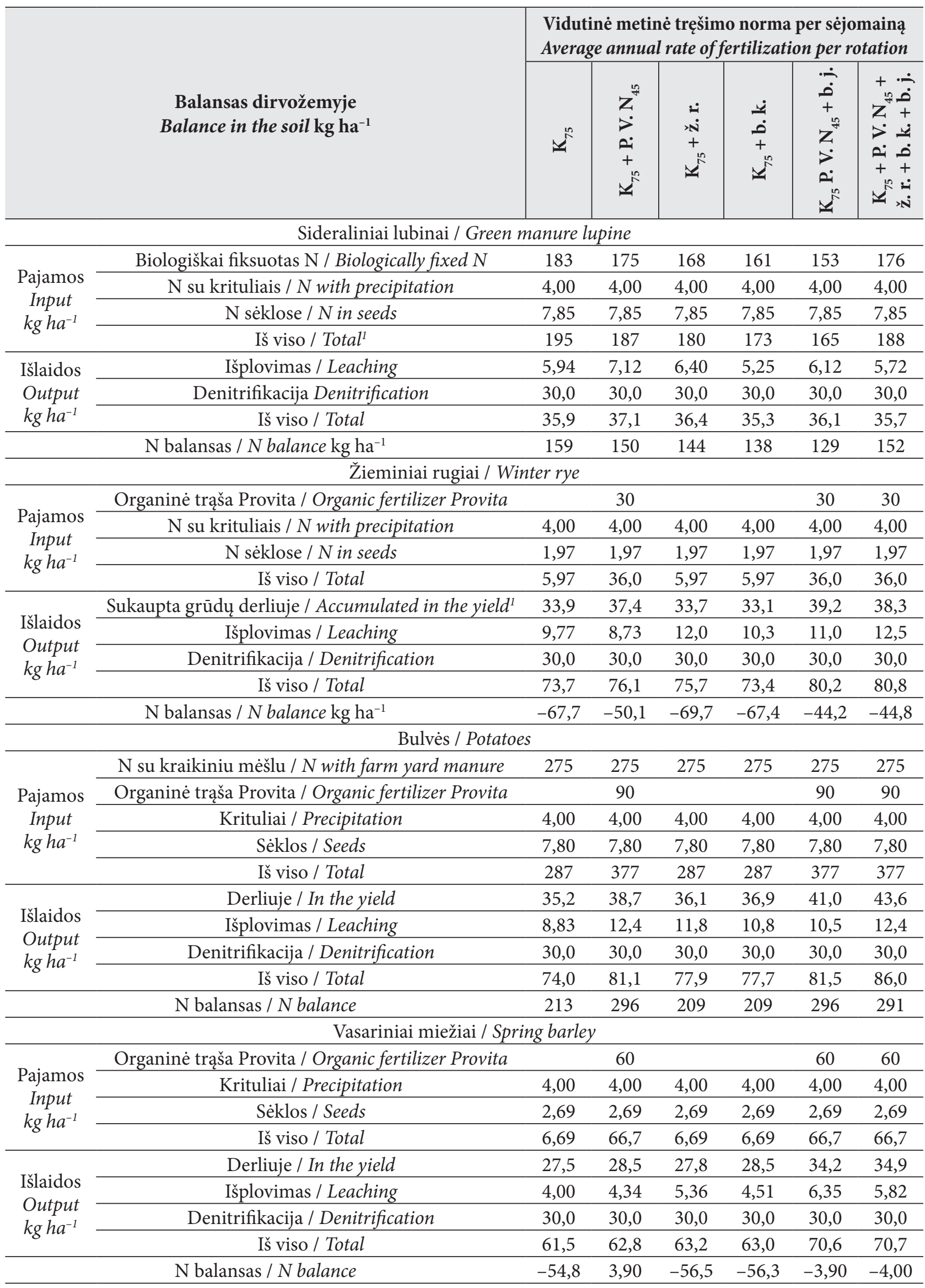




\begin{tabular}{|c|c|c|c|c|c|c|}
\hline \multicolumn{7}{|l|}{3 lentelè (tęsinys) } \\
\hline \multirow[b]{2}{*}{$\begin{array}{l}\text { Balansas dirvožemyje } \\
\text { Balance in the soil } \mathrm{kg} \mathrm{ha}^{-1}\end{array}$} & \multicolumn{6}{|c|}{$\begin{array}{l}\text { Vidutinè metinè tręšimo norma per sèjomainą } \\
\text { Average annual rate of fertilization per rotation }\end{array}$} \\
\hline & $v^{n}$ & $\begin{array}{l}z^{8} \\
z^{8} \\
0 \\
+ \\
z^{10}\end{array}$ & \begin{tabular}{l}
$\dot{4}$ \\
N \\
+ \\
\multirow{2}{k}{}
\end{tabular} & $\begin{array}{l}\dot{y} \\
\dot{0} \\
+\end{array}$ & 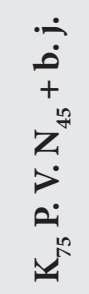 & 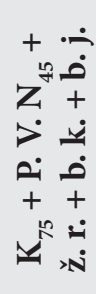 \\
\hline $\begin{array}{l}\text { Vidutinès metinès balanso pajamos } \\
\text { Average annual banace input } \mathrm{kg} \mathrm{ha}^{-1}\end{array}$ & 124 & 167 & 120 & 118 & 161 & 167 \\
\hline $\begin{array}{l}\text { Vidutinès metinès balanso išlaidos } \\
\text { Average annual balance output } \mathrm{kg} \mathrm{ha}^{-1}\end{array}$ & 61,3 & 64,3 & 63,3 & 62,4 & 67,1 & 68,3 \\
\hline $\begin{array}{l}\text { Vidutinis } \mathrm{N} \text { balansas per sèjomainą } \\
\text { Average } \mathrm{N} \text { balance per rotation }\end{array}$ & 62,7 & 103 & 56,7 & 55,6 & 93,9 & 98,7 \\
\hline $\begin{array}{l}\left.\text { Azoto sunaudojimas \% (Pajamos / Išlaidos }{ }^{\star} 100\right) \\
\left.\quad \text { N consumption \% (Output / Input }{ }^{*} 100\right)\end{array}$ & 49,4 & 38,5 & 52,8 & 52,9 & 41,7 & 40,9 \\
\hline
\end{tabular}

Trąšos: P. V. - Provita; ž. r. - žieminių rapsų žalioji trąša; b. k. - Biokal; b. j. - Biojodis.

Fertilizers: P. V. - Provita; w. r. - winter rapeseed green manure; $b . k$. -Biokal; b. j. - Biojodis.

$33,1-39,2 \mathrm{~kg} \mathrm{ha}^{-1}$, bulvių gumbuose - 35,2-43,6, o miežių grūduose - 27,5-34,9 $\mathrm{kg} \mathrm{ha}^{-1}$. Apie $30 \mathrm{~kg} \mathrm{ha}^{-1} \mathrm{~N}$ iš dirvožemio dèl denitrifikacijos buvo prarasta dujinių nuostolių pavidalu. Iš dirvožemio išsiplovęs $\mathrm{N}$ kiekis priklausè nuo augalų tręšimo ir jų vietos sejomainoje: mažiau $\mathrm{N}$ išsiplove lubinų ir miežių laukuose - atitinkamai $5,25-7,12$ ir 4,00-6,35 $\mathrm{kg} \mathrm{ha}^{-1}$. Žieminiuose rugiuose, augusiuose po sideralinių lubinų, ir méšlu tręštose bulvèse $\mathrm{N}$ iš dirvožemio išsiplovè daugiau - atitinkamai 8,73-12,5 ir 8,83-12,4 $\mathrm{kg} \mathrm{ha}^{-1}$.

Sideralinių lubinų lauke $\mathrm{N}$ balanso pajamos išlaidas viršijo 129-159 $\mathrm{kg} \mathrm{ha}^{-1}$. Bulvių lauke, tik méšlu tręštuose laukeliuose, šios augalų maisto medžiagos balanso pajamos išlaidas viršijo 209-213, o bulves patręšus ir Provita - net 291-296 kg ha-1. Rugius patręšus trąša Provita, $\mathrm{N}$ balanso pajamos buvo 44,2-50,1, o šia trąša netręšus - net $67,4-69,7 \mathrm{~kg} \mathrm{ha}^{-1}$ mažesnès nei išlaidos. Miežių lauke $\mathrm{N}$ balansas gautas mažiau neigiamas negu auginant rugius, kur azoto organine trąša Provita netręštuose laukeliuose šio balanso pajamos $54,8-56,5 \mathrm{~kg} \mathrm{ha}^{-1}$ viršijo išlaidas, o patręšus, $\mathrm{N}$ balansas gautas artimas nuliui.

Augalų maisto medžiagos iš organinių trąšu atsipalaiduoja palaipsniui ir jų poveikis augalų derliui, priklausomai nuo įvairių veiksnių, tęsiasi nuo 3-4 iki 7-8 metų (Krištaponyte, 1996; Tri- polskaja, 2005). Todèl lubinų žaliojoje trąšoje sukauptas augalų maisto medžiagas naudoja rugiai, o bulvèms įterptame kraikiniame mèšle esančiomis medžiagomis - bulvès ir po jų augantys miežiai.

Nors mūsų atliktuose tyrimuose visuose eksperimento laukeliuose vidutinis metinis $\mathrm{N}$ balansas per sejjomainą gautas teigiamas, tačiau dèl tręšimo Provita žemès ūkio augalų derlius turèjo tendenciją didèti. Teigiamą $\mathrm{N}$ balansą dirvožemyje palaikyti naudinga, nes augalai savo mitybai gali panaudoti tik iš organinès medžiagos i mineralines formas atsipalaidavusị azotą.

Mūsų atliktų tyrimų duomenimis, augalų netręšus trąša Provita dèl išplovimo bei denitrifikacijos augalų derlius neteko 49,4-52,9, o šia trąša tręšus - 38,5-41,7 \% ị dirvožemi patekusio azoto.

Fosforo balansas dirvožemyje. Šios augalų maisto medžiagos per sejjomainą balanso pajamas sudare vieną kartą, bulvèms ịterptas méšlas, o nedideli jo kiekiai ị dirvožemi pateko su augalu sẻklomis (4 lentelè). Fosforo balanso išlaidos - tai žemès ūkio augalų derliuje sukauptas ir iš dirvožemio išplautas šio elemento kiekis.

Sideralinių lubinų séjomainos lauke $\mathrm{P}_{2} \mathrm{O}_{5}$ balansas dirvožemyje gautas artimas nuliui - apie $2 \mathrm{~kg} \mathrm{ha}^{-1}$ šios augalų maisto medžiagos pateko su lubinų sẻklomis ir apie $0,500 \mathrm{~kg} \mathrm{ha}^{-1}$ išsiplovè. 
4 lentelè. Fosforo apykaita ekologinëje žemdirbystès sistemoje

Table 4. Metabolism of phosphorus in organic farming system

\begin{tabular}{|c|c|c|c|c|c|c|c|}
\hline \multirow{2}{*}{\multicolumn{2}{|c|}{$\begin{array}{c}\mathrm{P}_{2} \mathrm{O}_{5} \text { balansas dirvožemyje } \mathrm{kg} \mathrm{ha}^{-1} \\
\mathrm{P}_{2} \mathrm{O}_{5} \text { balance in the soil, } \mathrm{kg} \mathrm{ha^{-1 }}\end{array}$}} & \multicolumn{6}{|c|}{$\begin{array}{l}\text { Vidutinè metinè tręšimo norma per sèjomainą } \mathrm{kg} \mathrm{ha}^{-1} \\
\text { Average annual rate of fertilization per rotation, } \mathrm{kg} \mathrm{ha}^{-1}\end{array}$} \\
\hline & & $\underbrace{n}$ & $\begin{array}{l}Z^{\&} \\
z^{\circ} \\
\underbrace{\circ} \\
\underbrace{n}\end{array}$ & 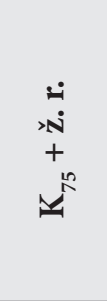 & $\begin{array}{l}\dot{2} \\
\dot{+} \\
\dot{n}\end{array}$ & 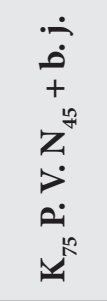 & 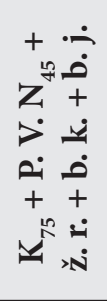 \\
\hline \multicolumn{8}{|c|}{ Sideraliniai lubinai / Green manure lupin } \\
\hline \multirow{2}{*}{$\begin{array}{l}\text { Pajamos kg ha-1 } \\
\text { Input, } k g h a^{-1}\end{array}$} & Séklos / Seeds & 1,97 & 1,97 & 1,97 & 1,97 & 1,97 & 1,97 \\
\hline & Iš viso / Total & 1,97 & 1,97 & 1,97 & 1,97 & 1,97 & 1,97 \\
\hline \multirow{3}{*}{$\begin{array}{l}\text { Išlaidos } \mathrm{kg} \mathrm{ha}^{-1} \\
\text { Output, } \mathrm{kg} \mathrm{ha}^{-1}\end{array}$} & Išplovimas / Leaching & 0,770 & 0,827 & 0,584 & 0,611 & 0,520 & 0,508 \\
\hline & Iš viso / Total & 0,770 & 0,827 & 0,584 & 0,611 & 0,520 & 0,508 \\
\hline & Balansas / Balance & 1,20 & 1,14 & 1,39 & 1,36 & 1,45 & 1,46 \\
\hline \multicolumn{8}{|c|}{ Žieminiai rugiai / Winter rye } \\
\hline \multirow{2}{*}{$\begin{array}{l}\text { Pajamos kg ha-1 } \\
\text { Input, } k g h a^{-1}\end{array}$} & Sèklos / Seeds & 1,05 & 1,05 & 1,05 & 1,05 & 1,05 & 1,05 \\
\hline & Iš viso / Total & 1,05 & 1,05 & 1,05 & 1,05 & 1,05 & 1,05 \\
\hline \multirow{4}{*}{$\begin{array}{l}\text { Išlaidos } \mathrm{kg} \mathrm{ha}^{-1} \\
\text { Output, } \mathrm{kg} \mathrm{ha}^{-1}\end{array}$} & Derlius / Yield & 18,1 & 20,0 & 18,0 & 17,7 & 21,0 & 20,4 \\
\hline & Išplovimas / Leaching & 1,53 & 1,47 & 1,02 & 1,47 & 1,27 & 1,75 \\
\hline & Iš viso / Total & 19,6 & 21,5 & 19,0 & 19,2 & 21,3 & 22,2 \\
\hline & Balansas / Balance & $-18,5$ & $-20,5$ & $-18,0$ & $-18,2$ & $-20,3$ & $-21,2$ \\
\hline \multicolumn{8}{|c|}{ Bulvès / Potatoe } \\
\hline \multirow{3}{*}{$\begin{array}{l}\text { Pajamos kg ha-1 } \\
\text { Input, } k g h a^{-1}\end{array}$} & Kraikinis méšlas / Farm yard manure & 145 & 145 & 145 & 145 & 145 & 145 \\
\hline & Sèklos / Seeds & 2,46 & 2,46 & 2,46 & 2,46 & 2,46 & 2,46 \\
\hline & Iš viso / Total & 147 & 147 & 147 & 147 & 147 & 147 \\
\hline \multirow{4}{*}{$\begin{array}{l}\text { Išlaidos } \mathrm{kg} \mathrm{ha}^{-1} \\
\text { Output, } \mathrm{kg} \mathrm{ha}^{-1}\end{array}$} & Derlius / Yield & 11,1 & 12,2 & 11,4 & 11,6 & 12,9 & 13,7 \\
\hline & $\begin{array}{l}\text { Išplovimas } \\
\text { Leaching }\end{array}$ & 0,399 & 0,632 & 0,425 & 0,511 & 0,602 & 0,779 \\
\hline & Iš viso / Total & 11,5 & 12,8 & 11,8 & 12,1 & 13,5 & 14,5 \\
\hline & Balansas / Balance & 136 & 134 & 135 & 135 & 134 & 133 \\
\hline \multicolumn{8}{|c|}{ Vasariniai miežiai / Spring barley } \\
\hline \multirow{2}{*}{$\begin{array}{l}\text { Pajamos } \mathrm{kg} \mathrm{ha}^{-1} \\
\text { Input, } \mathrm{kg} \mathrm{ha} a^{-1}\end{array}$} & Sèklos / Seeds & 1,60 & 1,60 & 1,60 & 1,60 & 1,60 & 1,60 \\
\hline & Iš viso / Total & 1,60 & 1,60 & 1,60 & 1,60 & 1,60 & 1,60 \\
\hline \multirow{3}{*}{$\begin{array}{l}\text { Išlaidos } \mathrm{kg} \mathrm{ha}^{-1} \\
\text { Output, } \mathrm{kg} \mathrm{ha}^{-1}\end{array}$} & Derlius / Yield & 16,4 & 16,9 & 16,5 & 16,9 & 20,4 & 20,8 \\
\hline & Išplovimas / Leaching & 0,301 & 0,468 & 0,378 & 0,403 & 0,487 & 0,536 \\
\hline & Iš viso / Total & 16,7 & 17,4 & 16,9 & 17,3 & 20,9 & 21,3 \\
\hline & Balansas / Balance & $-15,1$ & $-15,8$ & $-15,3$ & $-15,7$ & $-19,3$ & $-19,7$ \\
\hline \multicolumn{8}{|c|}{ Vidutiniškai per sèjomainą / On average per crop rotation } \\
\hline \multicolumn{2}{|c|}{$\begin{array}{l}\text { Vidutinès metinès balanso pajamos } \\
\text { Average annual balance input }\end{array}$} & 37,9 & 37,9 & 37,9 & 37,9 & 37,9 & 37,9 \\
\hline \multicolumn{2}{|c|}{$\begin{array}{l}\text { Vidutinès metinès balanso išlaidos } \\
\text { Average annual balance output }\end{array}$} & 12,1 & 13,1 & 12,1 & 12,3 & 14,1 & 14,6 \\
\hline \multicolumn{2}{|c|}{$\begin{array}{l}\text { Vidutinis } \mathrm{P}_{2} \mathrm{O}_{5} \text { balansas per sëjomainą } \\
\text { Average } \mathrm{P}_{2} \mathrm{O}_{5} \text { balance per rotation }\end{array}$} & 25,8 & 24,8 & 25,8 & 25,6 & 23,8 & 23,3 \\
\hline \multicolumn{2}{|c|}{$\begin{array}{l}\left.\text { Fosforo sunaudojimas \% (Pajamos / Išlaidos }{ }^{\star} 100\right) \\
\left.\text { Phosphorus consumption (Input / Output }{ }^{*} 100\right)\end{array}$} & 31,9 & 34,6 & 31,9 & 32,4 & 37,2 & 38,5 \\
\hline
\end{tabular}

Trąšos: P. V. - Provita; ž. r. - žieminių rapsų žalioji trąša; b. k. - Biokal; b. j. - Biojodis.

Fertilizers: P. V. - Provita; w. r. - winter rapeseed green manure; b. k. - Biokal; b. j. - Biojodis. 
Žieminių rugių lauke neigiamą fosforo balansą iš esmès lèmé rugių grūdu derlius, kuriame buvo sukaupta 17,7-21,0 $\mathrm{kg} \mathrm{ha}^{-1} \mathrm{P}_{2} \mathrm{O}_{5}$. Bulvèms su kraikiniu méšlu buvo ịterpta ir $145 \mathrm{~kg} \mathrm{ha}^{-1} \mathrm{P}_{2} \mathrm{O}_{5}$, todèl šios augalų maisto medžiagos balansas čia gautas itin teigiamas. Miežių, kaip ir rugių sèjomainos lauke, daugiausia dèl sukaupimo grūdų derliuje, $\mathrm{P}_{2} \mathrm{O}_{5}$ balansas gautas neigiamas.

Vieną kartą per sejjomainą ịterpta $50 \mathrm{t} \mathrm{ha}^{-1}$ kraikinio méšlo norma lèmé teigiamą šios augalų maisto medžiagos balansą, nes augalai derliuje fosforo sukaupia mažiau negu azoto ir kalio, o nuostoliai dèl išplovimo nebuvo dideli. Nors lubinai fosforo trąšomis tręšti nebuvo, tačiau jie buvo užarti žaliajai trąšai, kur iš dirvožemio sukauptu fosforu pasinaudojo po lubinų augę žieminiai rugiai. $\mathrm{P}_{2} \mathrm{O}_{5}$ balanso pajamos $23,3-25,8 \mathrm{~kg} \mathrm{ha}^{-1}$ viršijo išlaidas. Fosforas geriau buvo įsisavintas (34,6-38,5 \%) organine trąša Provita tręštuose laukeliuose, užaugo didesnis žemès ūkio augalų derlius, o šia trąša netręštuose laukeliuose foforo isisavinta 31,9-32,4 \%.

Kalio balansas dirvožemyje. Šios augalų maisto medžiagos balanso pajamos - visiems augalams itterptos natūralios mineralinès kalio trąšos Kornkali ir Patentkali, o taip pat (kaip azoto ir fosforo) nedidelis kalio kiekis ị dirvožemi pateko su augalų sẻklomis. Ypač daug kalio $\left(310 \mathrm{~kg} \mathrm{ha}^{-1} \mathrm{~K}_{2} \mathrm{O}\right)$ su kraikiniu méšlu buvo įterpta bulvių lauke.

Kalio balanso išlaidos - tai jo sukaupimas žemès ūkio augalų derliuje ir nuostoliai dèl išplovimo. Rugiu ir miežių grūdų derliuje kalio sukaupta nedaug - atitinkamai $10,6-12,5$ ir $11,0-13,9 \mathrm{~kg} \mathrm{ha}^{-1} \mathrm{~K}_{2} \mathrm{O}$. Šios augalų maisto medžiagos nuostoliai dèl išplovimo sideralinių lubinų, rugių ir miežių sèjomainos laukuose buvo apie $20 \mathrm{~kg} \mathrm{ha}^{-1} \mathrm{~K}_{2} \mathrm{O}$. Měšlu ir mineralinèmis kalio trąšomis tręštų bulvių lauke daugiau $\mathrm{K}_{2} \mathrm{O}$ sukauta gumbuose, o išsiplove atitinkamai 58,0-71,7 ir 37,1$44,8 \mathrm{~kg} \mathrm{ha}^{-1}$. Tačiau bulvių lauke balanso pajamos net $327-345 \mathrm{~kg} \mathrm{ha}^{-1}$ viršijo jo išlaidas. Sideralinių lubinų, žieminių rugiu ir vasarinių miežių laukuose kalio balanso pajamos išlaidas viršijo mažiau - atitinkamai 48,3-52,9; 19,3-35,0 ir 31,2-41,0 $\mathrm{kg} \mathrm{ha}^{-1}$.

Vidutinis kalio balansas per sejjomainą gautas iš esmès teigiamas - vidutiniškai kasmet $\mathrm{K}_{2} \mathrm{O}$ i dirvožemi buvo ịterpta net $107-119 \mathrm{~kg} \mathrm{ha}^{-1}$ daugiau negu sukaupta žemés ūkio augalų derliuje ir prarasta dèl išplovimo.

\section{5 lentelè. Kalio apykaita ekologinëje žemdirbystės sistemoje}

Table 5. Metabolism of potassium in organic farming system

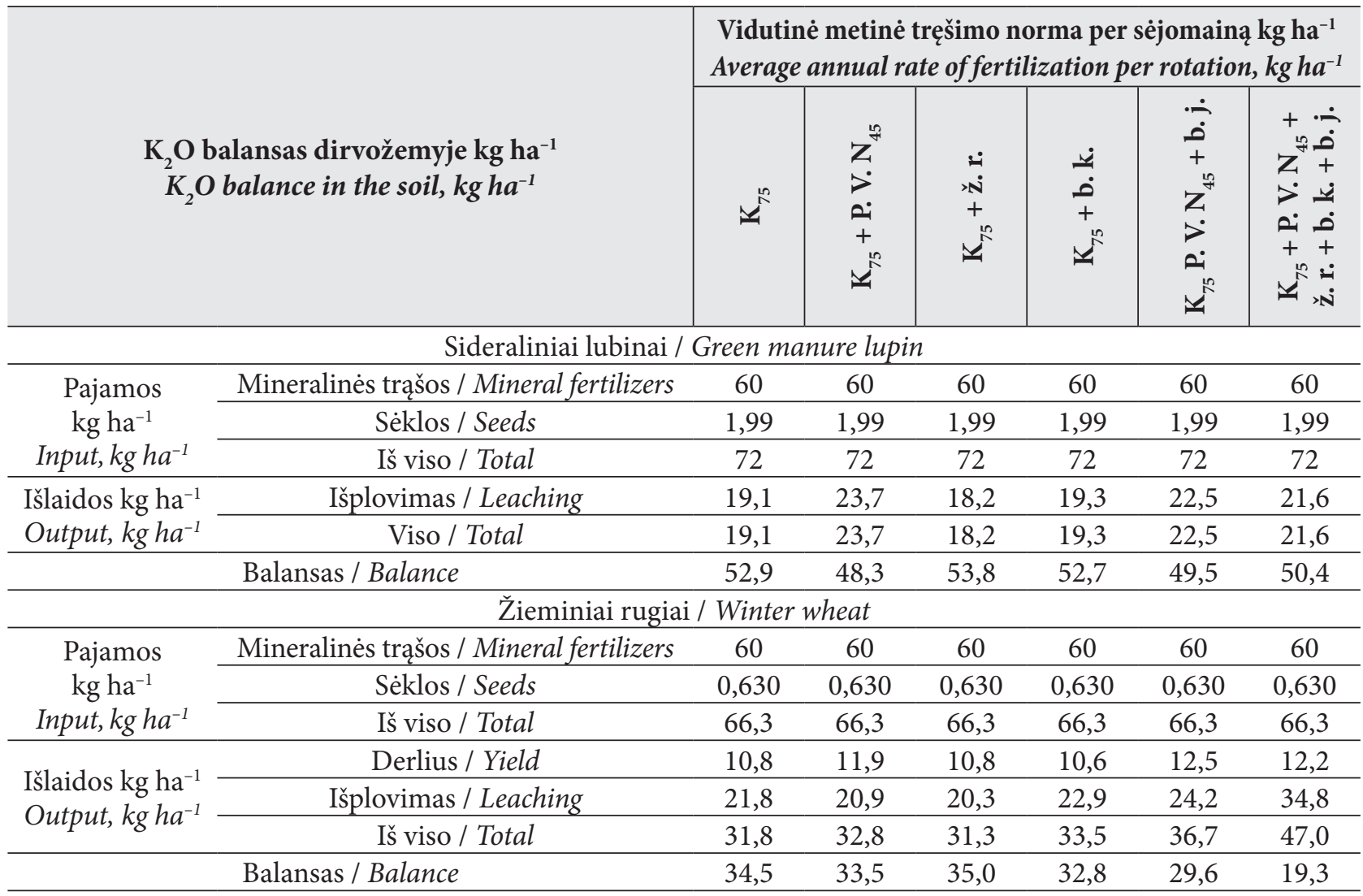




\begin{tabular}{|c|c|c|c|c|c|c|c|}
\hline \multicolumn{8}{|c|}{5 lentelè (tęsinys) } \\
\hline \multirow{2}{*}{\multicolumn{2}{|c|}{$\begin{array}{l}\mathrm{K}_{2} \mathrm{O} \text { balansas dirvožemyje } \mathrm{kg} \mathrm{ha}^{-1} \\
\mathrm{~K}_{2} \mathrm{O} \text { balance in the soil, } \mathrm{kg} \mathrm{ha}^{-1}\end{array}$}} & \multicolumn{6}{|c|}{$\begin{array}{l}\text { Vidutinè metinè tręšimo norma per sėjomainą } \mathrm{kg} \mathrm{ha}^{-1} \\
\text { Average annual rate of fertilization per rotation, } \mathrm{kg} \mathrm{ha}^{-1}\end{array}$} \\
\hline & & $\hat{~}$ & $z^{2}$ & $\stackrel{\dot{M}}{\dot{N}}$ & $\stackrel{\dot{y}}{\dot{1}}$ & $\begin{array}{l}\dot{\dot{m}} \\
\dot{+} \\
z^{2}\end{array}$ & 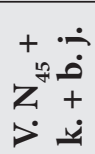 \\
\hline \multirow{4}{*}{$\begin{array}{c}\text { Pajamos } \\
\mathrm{kg} \mathrm{ha}^{-1} \\
\text { Input, } k g h a^{-1}\end{array}$} & Kraikinis méšlas / Farm yard manure & 310 & 310 & 310 & 310 & 310 & 310 \\
\hline & Mineralinès trąšos / Mineral fertilizers & 120 & 120 & 120 & 120 & 120 & 120 \\
\hline & Sèklos / Seeds & 12,8 & 12,8 & 12,8 & 12,8 & 12,8 & 12,8 \\
\hline & Iš viso / Total & 443 & 443 & 443 & 443 & 443 & 443 \\
\hline \multirow{3}{*}{$\begin{array}{l}\text { Išlaidos } \mathrm{kg} \mathrm{ha}^{-1} \\
\text { Output, } \mathrm{kg} \mathrm{ha}^{-1}\end{array}$} & Derlius / Yield & 58,0 & 63,8 & 59,5 & 60,8 & 67,4 & 71,7 \\
\hline & Išplovimas / Leaching & 37,1 & 34,9 & 44,8 & 38,4 & 37,3 & 44,4 \\
\hline & Iš viso / Total & 95,1 & 98,7 & 104 & 99,2 & 105 & 116 \\
\hline & Balansas / Balance & 345 & 344 & 339 & 344 & 338 & 327 \\
\hline \multicolumn{8}{|c|}{ Vasariniai miežiai / Spring barley } \\
\hline \multirow{3}{*}{$\begin{array}{c}\text { Pajamos } \\
\mathrm{kg} \mathrm{ha}^{-1} \\
\text { Input, } \mathrm{kg} \mathrm{ha}^{-1} \\
\end{array}$} & Mineralinès trąšos / Mineral fertilizers & 60 & 60 & 60 & 60 & 60 & 60 \\
\hline & Sëklos / Seeds & 1,07 & 1,07 & 1,07 & 1,07 & 1,07 & 1,07 \\
\hline & Iš viso / Total & 61,1 & 61,1 & 61,1 & 61,1 & 61,1 & 61,1 \\
\hline \multirow{3}{*}{$\begin{array}{l}\text { Išlaidos } \mathrm{kg} \mathrm{ha}^{-1} \\
\text { Output, } \mathrm{kg} \mathrm{ha}^{-1}\end{array}$} & Derlius / Yield & 11,0 & 11,4 & 11,1 & 11,4 & 13,7 & 13,9 \\
\hline & Išplovimas / Leaching & 10,5 & 10,3 & 9,02 & 11,6 & 14,0 & 16,0 \\
\hline & Iš viso / Total & 21,5 & 21,7 & 20,1 & 23,0 & 27,7 & 29,9 \\
\hline & Balansas / Balance & 39,6 & 39,4 & 41,0 & 38,1 & 33,4 & 31,2 \\
\hline \multicolumn{8}{|c|}{ Vidutiniškai per sėjomainą / On average per crop rotation } \\
\hline \multicolumn{2}{|c|}{$\begin{array}{l}\text { Vidutinès metinès balanso pajamos } \\
\text { Average annual balance input }\end{array}$} & 161 & 161 & 161 & 161 & 161 & 161 \\
\hline \multicolumn{2}{|c|}{$\begin{array}{l}\text { Vidutinès metinès balanso išlaidos } \\
\text { Average annual balance output }\end{array}$} & 41,9 & 44,2 & 43,4 & 43,8 & 48,0 & 53,6 \\
\hline \multicolumn{2}{|c|}{$\begin{array}{l}\text { Vidutinis } \mathrm{K}_{2} \mathrm{O} \text { balansas per sėjomainą } \\
\text { Average } \mathrm{K}_{2} \mathrm{O} \text { balance per rotation }\end{array}$} & 119 & 117 & 118 & 117 & 113 & 107 \\
\hline \multicolumn{2}{|c|}{$\begin{array}{l}\text { Kalio sunaudojimas \% / (Pajamos / Išlaidos * 100) } \\
\text { Consumption of } \mathrm{K}_{2} \mathrm{O} /\left(\text { Input / Output }{ }^{*} 100\right)\end{array}$} & 26,0 & 27,4 & 27,0 & 27,2 & 29,8 & 33,3 \\
\hline
\end{tabular}

Trąšos: P. V. - Provita; ž. r. - žieminių rapsų žalioji trąša; b. k. - Biokal; b. j. - Biojodis.

Fertilizers: P. V. - Provita; w. r. - winter rapeseed green manure; b. k. - Biokal; b. j. - Biojodis.

Tai patvirtina ir Joniškèlio bandymų stoties ekologinèje žemdirbystès sistemoje atliktų tyrimų duomenys, kai augalų tręšimui panaudojus tik žaliąją trąšą pagrindinių mitybos elementų NPK balansas buvo neigiamas, tačiau, augalų tręšimui panaudojus žaliąją trąšą ir mèšlą, dirvožemio NP balansas buvo teigiamas, o $\mathrm{K}$ - perteklinis (Masilionytė, Maikštėnienè, 2010).

Vidutinis kalio sunaudojimas lauko sejjomainoje nebuvo didelis, tačiau kaip ir fosforo didesnis buvo organine azoto trąša Provita tręštuose laukeliuose - 27,4-33,3 \%, o šia trąša netręštuose $-26,0-27,2 \%$.

\section{Ekologinio tręšimo ịtaka dirvožemio agrocheminèms savybèms}

Dirvožemyje esant per mažam augalų maisto medžiagų kiekiui, jų gali nepakakti normaliai žemès ūkio augalų mitybai, o esant maisto elementų pertekliui - gali iš dirvožemio išsiplauti ir teršti aplinką (Sieling et al., 1999; Mažvila et al., 2009; Rutkowska, Fotyma, 2009).

Mūsų atliktuose tyrimuose, vieną kartą per sèjomainą ịterpus bulvèms $50 \mathrm{t} \mathrm{ha}^{-1}$ méšlo, užarus lubinus žaliajai trąšai ir žieminių rugių bei vasarinių miežių šiaudus, humuso kiekis dirvožemyje nesumažèjo (6 lentelè). 
6 lentelè. Ekologinio tręšimo ịtaka dirvožemio agrocheminiams rodikliams

Table 6. Influence of eco-fertilization on soil agrochemical properties

\begin{tabular}{|c|c|c|c|c|c|c|}
\hline \multirow{2}{*}{$\begin{array}{c}\text { Tręšimo sistema } \\
\text { Fertilization system }\end{array}$} & \multicolumn{2}{|c|}{ Humuso kiekis \% / Humus content, \% } & \multicolumn{2}{|c|}{$\mathrm{P}_{2} \mathrm{O}_{5} \mathrm{mg} \mathrm{kg}^{-1}$} & \multicolumn{2}{|c|}{$\mathrm{K}_{2} \mathrm{O} \mathrm{mg} \mathrm{kg}^{-1}$} \\
\hline & 2006 & 2009 & 2006 & 2009 & 2006 & 2009 \\
\hline $\mathrm{K}_{75}$ & 1,86 & 1,86 & 217 & 220 & 135 & 183 \\
\hline $\mathrm{N}_{45} \mathrm{~K}_{75}$ & 1,84 & 1,83 & 214 & 221 & 137 & 183 \\
\hline $\mathrm{K}_{75}+$ ž.r. / w.r. & 1,87 & 1,76 & 217 & 224 & 139 & 184 \\
\hline $\mathrm{K}_{75}+$ b. k. / w.r. & 1,80 & 1,81 & 224 & 224 & 140 & 188 \\
\hline $\mathrm{N}_{45} \mathrm{~K}_{75}+$ b. j. & 1,77 & 1,78 & 219 & 217 & 136 & 186 \\
\hline $\mathrm{N}_{45} \mathrm{~K}_{75}+$ ž. r. / w. r. + b. k. + b. j. & 1,83 & 1,82 & 217 & 216 & 137 & 178 \\
\hline Vidurkis / Average & 1,83 & 1,81 & 218 & 220 & 137 & 184 \\
\hline $\mathrm{R}_{05} / L S D_{05}$ & 0,191 & 0,218 & 23,0 & 25,2 & 17,6 & 21,0 \\
\hline
\end{tabular}

Trąšos: P. V. - Provita; ž. r. - žieminių rapsų žalioji trą̧̌a; b. k. - Biokal; b. j. - Biojodis.

Fertilizers: P. V. - Provita; w. $r$. - winter rapeseed green manure; $b$. $k$. - Biokal; b. j. - Biojodis.

Didelio fosforingumo dirvožemyje fosforo balansui esant silpnai teigiamam, judriojo fosforo kiekis dirvožemyje per sejjomainos rotaciją beveik nepakito.

Panašūs duomenys gauti ir ilgalaikiame žemès ūkio augalų tręšimo bandyme: kai dirvožemyje judriojo fosforo buvo daugiau kaip $300 \mathrm{mg} \mathrm{kg}^{-1}$, jo kiekis dèl tręšimo fosforo trąšomis beveik nedidèjo (Mažvila et al., 2009).

Nors judriojo $\mathrm{K}_{2} \mathrm{O}$ prieš bandymo įrengimą dirvožemyje buvo mažiau negu fosforo, tačiau dèl gausaus tręšimo organinemis, taip pat mineralinèmis kalio trąšomis, kalio balansas dirvožemyje buvo akivaizdžiai perteklinis, o judriojo kalio kiekis dirvožemyje per sëjomainos rotaciją padidejo vidutiniškai $46 \mathrm{mg} \mathrm{kg}^{-1}$.

\section{Ekologinio tręšimo įtaka cheminių elementų išplovimui}

Cheminių elementų išplovimas priklauso nuo jų kiekio dirvožemyje, balanso, dirvožemio granuliometrinès sudèties, klimatinių sąlygų, auginamų augalų ir kitų veiksnių (Maquire, Sims, 2002; Adomaitis et al., 2008; Goss et al., 2010).

Mūsų atliktų tyrimų duomenimis, azoto išplovimas labiausiai priklausè nuo metų laiko, o mažiau - nuo žemès ùkio augalų tręšimo. Daugiau $\left(6,17-8,00 \mathrm{~kg} \mathrm{ha}^{-1}\right)$ azoto išsiplovè vasaros-rudens nei žiemos-pavasario $\left(0,900-1,30 \mathrm{~kg} \mathrm{ha}^{-1}\right)$ laikotarpiu (7 lentelè). Augalų tręšimas organine azoto trąša Provita turejo mažai ịtakos azoto išplovimui iš dirvožemio.

\section{7 lentelè. Cheminių elementų išplovimas ekologinėje sẻjomainoje}

\section{Table 7. Leaching of chemical elements in eco-rotation}

\begin{tabular}{|c|c|c|c|c|c|c|c|c|}
\hline \multirow{3}{*}{ 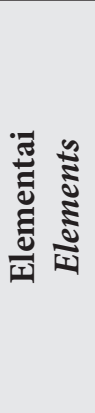 } & \multirow{3}{*}{$\begin{array}{l}\text { Tyrimų laikas } \\
\text { Period of studies }\end{array}$} & \multicolumn{7}{|c|}{$\begin{array}{l}\text { Vidutinè metinė tręšimo norma per sèjomainą } \mathrm{kg} \mathrm{ha}^{-1} \\
\text { Average annual fertilization rate per rotation, } \mathrm{kg} \mathrm{ha}^{-1}\end{array}$} \\
\hline & & $\underbrace{n}$ & $\begin{array}{l}z^{8} \\
z^{\circ} \\
x^{n}\end{array}$ & $\begin{array}{c}\dot{\vec{H}} \\
>\vec{N} \\
+ \\
\stackrel{k}{k}\end{array}$ & $\begin{array}{l}\ddot{n} \\
\dot{0} \\
+ \\
\ddot{n}\end{array}$ & 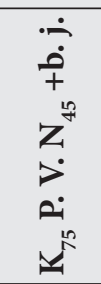 & 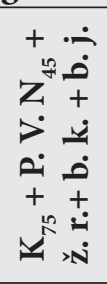 & $\varkappa^{2}$ \\
\hline & & \multicolumn{7}{|c|}{ Cheminių elementų išplovimas $\mathrm{kg} \mathrm{ha}^{-1} /$ Leaching of chemical elements, $\mathrm{kg} \mathrm{ha}^{-1}$} \\
\hline \multirow{2}{*}{$\mathrm{N}$} & Pavasaris / Spring & 0,960 & 1,30 & 1,16 & 0,900 & 1,06 & 1,11 & 0,165 \\
\hline & Ruduo / Autumn & 6,17 & 6,85 & 7,73 & 6,82 & 7,43 & 8,00 & 1,158 \\
\hline \multirow{2}{*}{$\mathrm{P}_{2} \mathrm{O}_{5}$} & Pavasaris / Spring & 0,222 & 0,196 & 0,091 & 0,201 & 0,176 & 0,245 & 0,0294 \\
\hline & Ruduo / Autumn & 0,528 & 0,653 & 0,511 & 0,548 & 0,544 & 0,648 & 0,1391 \\
\hline \multirow{2}{*}{$\mathrm{K}_{2} \mathrm{O}$} & Pavasaris / Spring & 5,20 & 4,30 & 2,40 & 3,30 & 4,00 & 5,70 & 0,697 \\
\hline & Ruduo / Autumn & 16,9 & 18,2 & 20,7 & 19,8 & 20,5 & 23,5 & 3,11 \\
\hline
\end{tabular}

Trąšos: P. V. - Provita; ž. r. - žieminių rapsų žalioji trąša; b. k. - Biokal; b. j. - Biojodis.

Fertilizers: P. V. - Provita; w. r. - winter rapeseed green manure; b. k. - Biokal; b. j. - Biojodis. 
Fosforo, palyginti su azotu, iš dirvožemio išsiplove mažiau, tačiau taip pat priklausè nuo metų laiko - daugiau $\left(0,431-0,551 \mathrm{~kg} \mathrm{ha}^{-1}\right)$ išsiplovè vasaros-rudens laikotarpiu.

Kalio balansui dirvožemyje esant pertekliniam, vasaros-rudens metu iš dirvožemio išsiplovè net 16,9-23,5 $\mathrm{kg} \mathrm{ha}^{-1} \mathrm{~K}_{2} \mathrm{O}$, o žiemos-pavasario laikotarpiu, kaip ir azoto bei fosforo, išsiplovè mažiau $-2,40-5,70 \mathrm{~kg} \mathrm{ha}^{-1}$.

\section{IŠVADOS}

Ekologineje žemdirbystès sistemoje, augalus tręšus méšlu, žaliąja trąša ir šiaudais, o taip pat - mineralinèmis kalio trąšomis, azoto, fosforo ir kalio balanso pajamos viršijo jų išlaidas atitinkamai $55,6-62,7 ; 23,3-25,8$ ir $107-119 \mathrm{~kg} \mathrm{ha}^{-1}$.

Rugius, bulves ir miežius patręšus ir azoto organine trąša Provita, azoto balanso pajamos viršijo išlaidas net $93,9-103 \mathrm{~kg} \mathrm{ha}^{-1}$, gerino fosforo ir kalio pasisavinimą.

Dèl ekologinių trąšų naudojimo humuso ir judriojo fosforo kiekis per sejjomainos rotaciją dirvožemyje beveik nepakito, o judriojo kalio kiekis dirvožemyje padidèjo $47 \mathrm{mg} \mathrm{kg}^{-1}$.

Cheminių elementų iš dirvožemio daugiau išsiplovè vasaros-rudens nei žiemos-pavasario laikotarpiu. Kiek daugiau išsiplove kalio, mažiau - azoto, o mažiausiai - fosforo.

Gauta 20140924

Priimta 20150330

\section{LITERATŪRA}

1. Adomaitis T., Vaišvila Z., Mažvila J., Staugaitis G., Fullen M. A. 2008. Influence of mineral fertilizers on nitrogen leaching. Acta Agriculturae Scandinavica. Vol. 58. P. 199-207.

2. Bachinger J., Stein-Bachinger K. 2000. Organic farming on large farms with special reference to Eastern Germany. In: M. J. Wilson, B. MaliszewskaKordybach, eds. Soil Quality, Sustainable Agriculture and Environmental Security in Central and Eastern Europe. Kluwer Academic Publishers Dordrecht. P. 125-137.

3. Brandt K., Mølgaard J. P. 2001. Organic agriculture: does it enhance or reduce the nutritional value of plant foods? Journal of the Science of Food and Agriculture. Vol. 81. No. 9. P. 924-931.

4. Bučienè A., Švedas A., Antanaitis S. 2003. Balances of the major nutrients $\mathrm{N}, \mathrm{P}$ and $\mathrm{K}$ at the farm and field level and some possibilities to improve com- parisions between actual and estimated crop yields. European Journal of Agronomy. Vol. 20. P. 53-62.

5. Clewer A. G., Scarisbrick D. H. 2001. Practical Statistics and Experimental Design for Plant and Crop Science. Chichester, UK: John Wiley \& Sons Ltd. $329 \mathrm{p}$.

6. Commission Regulation (EC) No. 889/2008 laying down detailed rules for the implementation of Council Regulation (EC) No. 834/2007 on organic production and labelling of organic products with regard to organic production, labelling and control (OL L 250, 200809 18, p. 1) [cited 2010-01-27]. Available from: http://eur-lex.europa

7. Council Regulation (EC) No. 834/2007 on organic production and labelling of organic products with regard to organic production, labelling and control and repealing Regulation (EEC) No. 2092/91 (OL L 189, 200707 20, p. 1) [cited 2010-01-27]. Available from: http://eur-lex.europa

8. Evans J. 1987. Nitrogen fixation and accretion of soil nitrogen by field-grown lupinus (Lupinus angustifolium). Field Crops Response. Vol. 16. No. 4. P. 309-322.

9. Fagerberg B., Salomon E., Steineck S. 1993. The Computer Program NPK-FLO. Department of Crop Production Science, Swedish University of Agricultural Sciences: International Publications.

10. Freyer B., Pericin C. 1996. Nutrient balance on organic farms. Agroforschung. Vol. 3. No. 1. P. 29-32.

11. Goss M. J., Ehlers W., Unc A. 2010. The role of lysimeters in the development of our understanding of processes in the vadose zone relevant to contamination of groundwater aquifers. Physics and Chemistry of the Earth. Vol. 35. P. 913-926.

12. Haraldsen T. K., Asdal A., Grasdalen C., Nesheim L., Ugland T. N. 1999. Nutrient balances and yields during conversion from conventional to organic cropping systems on silt loam and clay soils in Norway. Biological Agriculture and Horticulture. Vol. 17. P. 229-246.

13. HELCOM Recommendation 28E/5. Supersedes HELCOM Recommendations 7/3, 9/2 and 16/9. Adopted 15 November 2007, having regard to Article 20, Paragraph 1 b) of the Helsinki Convention.

14. Jablonskis J., Janukènienė R. 1978. Lietuvos upiu nuotékio kaita. $174 \mathrm{p}$.

15. Jankauskas B., Jankauskienė G., Švedas A. 2000. Derliaus energetinio įvertinimo skaičiavimo metodų palyginimas. Zemdirbyste-Agriculture. Nr. 72. P. 239-251.

16. Karklins A., Lipenite I. 2006. NPK balance calculation as a tool for sustainability assessment. Pochvovedenie i agrokhimiya. No. 2. S. 31-40.

17. Krištaponytė I. 1996. Tręšimo sistemų palyginimas sunkios granuliometrinès sudèties dirvožemiuose. Zemdirbyste-Agriculture. T. 56. Nr. 2. P. 54-63.

18. Lapinskas E. 2008. Azoto pokyčiai dirvožemyje ir jo reikšme augalams. $319 \mathrm{p}$. 
19. Mander Ü., Mikk M., Külvik M. 1999. Ecological and low intensity agriculture as contributors to landscape and biological diversity. Landscape and Urban Planning. Vol. 46. P. 169-177.

20. Maquire R. O., Sims J. T. 2002. Soil testing to predict phosphorus leaching. Journal of Environmental Quality. Vol. 5. P. 1601-1609.

21. Masilionytė L., Maikštenienè S. 2010. The influence of various organic fertilizers and catch crops on the balance of biogenic elements in the agrosystems. Zemdirbyste-Agriculture. Vol. 97. No. 2. P. 41-52.

22. Mažvila J., Pekarskas J., Arbačiauskas J. 2003. Ekologinès žemdirbystès ūkių dirvožemių agrocheminès savybės ir jų kaita. ZemdirbysteAgriculture. Vol. 83. No. 3. P. 66-76.

23. Mažvila J., Arbačiauskas J., Antanaitis A., Lubytė J., Adomaitis T., Vaišvila Z. 2009. Effects of longterm fertilization on soil agrochemical properties. Zemdirbyste-Agriculture. Vol. 96. No. 2. P. 35-52.

24. Niggli U., Alföldi T., Mäder P., Besson J. M. 1995. DOK - Versuch: vergleichende Langzeituntersuchungen in der drei Anbausystemen biologisch - Dynamisch, Organisch - biologich und Konvertionell. VI. Synthese, 1 und 2. Fruchtfolgeperiode. Schweizerische Landwirtschaftliche Forschung. Sonderhelft DOK. No. 4. P. 1-34.

25. Parris K. 1998. Agricultural nutrient balances as agrienvironmental indicators: an OECD perspective. Environmental Pollution. No. 102. P. 212-225.

26. Pekarskas J., Baltramaitytė D., Rutkovienė V. 2003. Ekologinio ūkininkavimo ittaka NPK balansui. Vagos. T. 59. Nr. 12. P. 81-85.

27. Pekarskas J. 2008. Tręšimas ekologinès gamybos ükiuose. Kaunas. 188 p.

28. Rutkowska A., Fotyma M. 2009. Calibration of Soil Test for Mineral Nitrogen in Poland. Communication in Soil Science and Plant Analysis. Vol. 40. P. 1-6.

29. Sieling K., Günter-Borstel, Teebken T., Hanus H. 1999. Soil mineral $\mathrm{N}$ and $\mathrm{N}$ net mineralization during autumn and winter under an oilseed rape-winter wheat-winter barley rotation in different crop management systems. The Journal of Agricultural Science. Vol. 132. P. 127-137.

30. Tamulis T. 1986. Pašaru chemine sudetis ir maistingumas. Vilnius: Mokslas. 277 p.

31. Tripolskaja L. 2005. Organinès trąšos ir ju poveikis aplinkai. Akademija. 214 p.
32. Watson C. A., Bengtsson H., Ebbelsvik M., Løes A. K., Myrbeck A., Salomon E., Schroeder J., Stocdale E. A. 2002. A review of farm-scale nutrient budgets for organic farms as a tool for management of soil fertility. Soil Use and Management. Vol. 18. P. 264-273.

Vilma Žèkaitè, Gediminas Staugaitis, Jonas Arbačiauskas, Juozas Pekarskas, Tomas Adomaitis, Donatas Šumskis, Zigmas Vaišvila

\section{INFLUENCE OF ORGANIC FERTILIZATION ON NPK BALANCE AND NUTRIENTS DYNAMICS IN THE SOIL}

\section{Sum mary}

The purpose of this study is to assess the balance of nitrogen, phosphorus and potassium in organic four-field rotation, to determine its effect on the chemical properties of light textured soil and leaching of chemical elements, assessing the suitability of this fertilization system for organic farming.

Studies of plant nutrient balance in the organic farming system were carried out in the period of 2006-2009 in a regular podzolized luvisol (IDE-p), sandy loam (Hapli-Albic Luvisol (LVA-ha), sandy loam). Soil arable layer $\mathrm{pH}_{\mathrm{KCl}}$ was 5.2 to $6.3 ; \mathrm{P}_{2} \mathrm{O}_{5} 190-253 ; \mathrm{K}_{2} \mathrm{O} 134-178 \mathrm{mg} \mathrm{kg}^{-1}$, and humus was $1.83 \%$. For field rotation, green manure lupine, winter rye, potatoes and spring barley were grown.

In the organic farming system, having fertilized crops with manure, green manure and straw, as well as with a mineral potassium fertilizer, the input of the balance of nitrogen, phosphorus and potassium exceeded the output by $55.6-62.7,23.3-25.8$ and $107-119 \mathrm{~kg} \mathrm{ha}^{-1}$, respectively.

Having fertilized rye, barley and potatoes with the organic nitrogen fertilizer "Provita", the input of nitrogen balance exceeded the output even by 93.9 to $103 \mathrm{~kg} \mathrm{ha}^{-1}$ and improved phosphorus and potassium uptake.

Due to the use of the organic fertilizer, the humus content and the amount of mobile phosphorus in the soil during crop rotation remained almost unchanged, while the available potassium content in the soil increased by $47 \mathrm{mg} \mathrm{kg}^{-1}$.

Leaching of chemical elements from the soil was more intensive in the summer-autumn than in the winter-spring period. Potassium was leached to a greater extent, nitrogen was leached less, while phosphorus was leached least.

Key words: agrochemical indices, balance, leaching, organic fertilizers 